\title{
The influence of selenium concentration and variations in selenoprotein genes on the CHEK2-dependent cancers
}

\author{
Satish Gupta ${ }^{*}$, Magdalena Muszynska², Katarzyna Jaworska-Bieniek', Grzegorz Sukiennicki', Katarzyna Kaczmarek', \\ Anna Jakubowska', Jan Lubinski ${ }^{1}$
}

From Annual Conference on Hereditary Cancers 2013

Szczecin, Poland. 26-27 September 2013

\section{Introduction}

Studies in the Polish population provided evidence that four founder mutations in CHEK2 gene (1100delC, IVS2 $+1 \mathrm{G}>\mathrm{A}, \mathrm{I157T}$, del5395) are associated with increased risk of cancers including breast, prostate, colon, kidney and thyroid. The substantial variability in cancer penetrance in mutation carriers can probably be explained by the influence of other genetic and/or environmental factors. Selenium is an essential component of several major metabolic pathways, including the antioxidant defense system and the immune system. It has been suggested that selenium and variations in selected selenoprotein genes may be risk factors for several cancer types.

\section{Aim}

The aim of study was to check if Se concentration and alteration in genes coding selenoproteins can be associated with cancer risk in CHEK2 mutation carriers and unselected patients.

\section{Material and method}

Biological samples (blood, serum, plasma) and clinical information have been collected from 826 CHEK2 mutation carriers - 670 healthy individuals and 156 cancer cases - including breast, gastrointestinal tract (colon, intestine, pancreas, stomach, gallbladder), respiratory system (lung, larynx), prostate, kidney, ovarian and others.

\footnotetext{
* Correspondence: satish1482@gmail.com

'Department of Genetics and Pathology, International Hereditary Cancer

Center, Pomeranian Medical University, Szczecin, Poland

Full list of author information is available at the end of the article
}

In the above groups cancer patients have been matched to unaffected individuals in ratio 1:2 or 1:1. The matching included CHEK2 mutation type, sex, year of birth, smoking, number and location of cancer among $\mathrm{I}^{\circ}$ relatives.

In all matched individuals Se concentration in serum/ plasma have been determined using ICP-MS and 4 SNPs in selenoprotein genes GPX1 (rs1050450), GPX4 (rs713041), TXNRD2 (rs1139793) and SEP15 (rs5845) have been analyzed using Taqman probes.

To assess the cancer risk in relation to Se level and/or studied alterations in selenoprotein genes the odds ratio have been calculated using conditional logistic regression for matched groups. In tested groups the cancer risk in relation to Se concentration was analyzed in quartiles. All statistical analyses were performed using $R$ software.

\section{Results}

In the group of the matched CHEK2 carriers mean selenium level was significantly lower in cancer patients than in healthy controls: $73.2 \mu \mathrm{g} / \mathrm{l}$ vs. $78.5 \mu \mathrm{g} / \mathrm{l}(\mathrm{p}=0.002)$. We found that the cancer risk decreased with increased Se concentration: individuals in $\mathrm{IV}^{\text {th }}$ quartile $(>86.28 \mu \mathrm{g} / \mathrm{l})$ in comparison to those in $\mathrm{I}^{\text {st }}$ quartile $(<65.81 \mu \mathrm{g} / \mathrm{l})$ have $\sim 2$-times lower cancer risk (OR=0.46; $\mathrm{p}=0.01)$. We also observed an association of $C H E K 2$ associated cancer risk depending on variants in selenoprotein genes. The data analysis indicates modest association of rs5845 in SEP15 with breast, rs 1050450 in GPX1 with prostate cancer and rs713041 in GPX4 with lung/larynx cancer risk. Influence of Se level on breast, prostate, lung and larynx cancer risk may be dependent on variants in selenoprotein genes. 


\section{Conclusions}

Our analyses clearly indicate that selenium can be a modifier of cancer risk in CHEK2 mutation carriers. The effect of selenium level in blood serum on cancer risk may be dependent upon genotypes in selenoprotein genes.

\section{Authors' details}

'Department of Genetics and Pathology, International Hereditary Cancer Center, Pomeranian Medical University, Szczecin, Poland. ${ }^{2}$ Read Gene SA, Szczecin, Poland

Published: 9 September 2015

doi:10.1186/1897-4287-13-S1-A13

Cite this article as: Gupta et al:: The influence of selenium

concentration and variations in selenoprotein genes on the

CHEK2-dependent cancers. Hereditary Cancer in Clinical Practice 2015

13(Suppl 1):A13.

Submit your next manuscript to BioMed Central and take full advantage of:

- Convenient online submission

- Thorough peer review

- No space constraints or color figure charges

- Immediate publication on acceptance

- Inclusion in PubMed, CAS, Scopus and Google Scholar

- Research which is freely available for redistribution 